\title{
CHAMADA PARA ARTIGOS
}

Convidamos os interessados em colaborar com a Revista Debates a
nos enviar seus manuscritos pelo site da revista (http://www.revistadebates.ufrgs.br).

O próximo número da publicação trará o Dossiê Opinião Pública, Eleições e Participação Política nas Democracias Contemporâneas, organizado pelos professores Denise Paiva (UFG), Pedro S. Mundim (UFG) e Helcimara Telles (UFMG). O dossiê tem como objetivo central reunir artigos que, a partir de diferentes perspectivas analíticas e metodológicas, discutam a relação entre democracia, participação política, opinião pública e eleições. O papel das eleições majoritárias e legislativas na consolidação das democracias contemporâneas, especialmente a dos países latino-americanos, tendo em vista o comportamento dos eleitores e das elites políticas, estudos sobre a formação da opinião pública e dos efeitos da mídia no processo de decisão das preferências e das condutas políticas, além das metodologias quantitativas e qualitativas utilizadas para se aferir de opinião pública, estão entre os temas que servirão de eixo fundamental para o próximo número.

A submissão dos artigos para o dossiê pode ser feita até o dia 26 de agosto de 2011. Lembramos, ainda, que aceitamos colaborações nas seções de artigos livres, de resenhas e de notas de pesquisa. 